\title{
An Improvement of Calcium Determination Technique in the Shell of Molluscs
}

\author{
Cristiane Soído ${ }^{1}$, Maurício Carvalho Vasconcellos ${ }^{2}$, Antônia Gonçalves Diniz ${ }^{1}$ and Jairo \\ Pinheiro $^{1 *}$ \\ ${ }^{I}$ Departamento de Ciências Fisiológicas; Instituto de Biologia; Universidade Federal Rural do Rio de Janeiro; km \\ 7; BR465; 23.890-000; Seropédica - RJ - Brasil. ${ }^{2}$ Departamento de Biologia; Fundação Oswaldo Cruz; Instituto \\ Oswaldo Cruz; Av. Brasil,4365; Manguinhos - RJ - Brasil
}

\begin{abstract}
The complexometric method is usually applied to quantitative calcium determination in different materials; however the application of this method to calcium determination in molluscs shells infers significant interferences to the results. The snail Bradybaena similaris, a terrestrial gastropod, was used as experimental model to the improvement of this method. The shells were calcinated and dissolved in nitric acid, the hydrogen peroxide was also used to clarify the medium after the acid addition. The calcination procedure and the use of nitric acid reduced the significantly the interferences, allowing a major degree of destruction of the organic substances of the shell. The improvement of the calcium determination technique usually employed showed calcium content of $874.24 \pm 56.617$ $m g$ of $\mathrm{CaCO}_{3} / g$ of ash in comparison to the conventional technique that allowed the determination of $607.79 \pm$ $67.751 \mathrm{mg}$ of $\mathrm{CaCO}_{3} / \mathrm{g}$ of shell, wet weight.
\end{abstract}

Key words: Snail, Bradybaena similaris, shell, calcium determination technique

\section{INTRODUCTION}

The ion calcium is one of the most important elements present in the shell of molluscs, mainly the gastropods, to which the shell is straightly related to protection of the animal against predators and to avoid the dehydration. But the shell is not an inert mineral structure. Calcium is a metal that exerts an essential role on the biology of the snails, once that, this ion is the main component of the snails shell, constituting an important limiting factor that determine the distribution and survival of the adult snails, oviposition rate, survival and development of eggs and the embryos (Thomas et al., 1974; Nduku and Harrison, 1976; Appleton, 1978; Dawies and Erasmus, 1984). The calcium ion still participates in many enzymatic reactions and is required to metabolic processes related to acid-basic equilibrium in the hemolymph (Sminia et al., 1977; De With and Sminia, 1980). Many physiological alterations may affect the calcium reserves in the shell and in the hemolymph of mollusks (Souza et al., 2000; Lira et al., 2000; Pinheiro, 1996).

Calcium determination in the shell of the snails is an important parameter that is widely used as an indirect evaluation of metabolic alterations,

*Author for correspondence: jps@ufrrj.br 
influence of the environment and conditions of stress on the physiology of molluscs (Paschoal and Amato, 1996; Brandolini and Amato, 2001; Moreira et al., 2003). The calcium present in the shell is predominantly found as calcium carbonate incorporated in the shell structure as calcite and aragonite crystals associated to the organic matrix, composed basically by conchiolin.

The technique widely used to calcium determination in molluscs is that described by Pinheiro and Amato (1995), where the results are expressed as ppm $\mathrm{CaCO}_{3} / \mathrm{g}$ of shell, wet weight, but this technique infers great error to the final values obtained in the determinations.

The purpose of this study was to improve the calcium determination technique in snails' shell described by Pinheiro and Amato (1995), aiming to eliminate or minimize factors that may interfere in the interpretation of the results obtained.

\section{MATERIAL AND METHODS}

Snails collection and maintenance - Specimens of Bradybaena similaris (Férussac, 1821) were collected from gardens located at Água Santa District, Rio de Janeiro, RJ, Brazil, maintained under laboratory conditions and fed with fresh lettuce, cabbage and carrot ad libitum. The snails were observed by their transparent shell to verify the occurrence of Postharmostomum gallinum Witenberg, 1923 metacercariae in the pericardial cavity, once that some snails may be naturally infected with this parasite and the parasitism by larval trematodes would change physiological parameters that are involved in the calcification of the shell in the mollusc.

The snails free of infection were transferred to glass vivaria, measuring $20 \times 12 \times 10.5 \mathrm{~cm}$, with a layer of soil, with $2.0 \mathrm{~cm}$, at the bottom, and moistened with tap water in alternate days (Moreira et al., 2003).

\section{Snails dissection and calcium determination}

After 20 days under laboratory conditions, the snails measuring $0.48 \mathrm{~cm}$ in shell diameter and weighing $11.5 \mathrm{~g}$ wet weight, were immersed in boiling water 30 seconds and had the soft tissues removed. The shells were dried at room temperature four days and weighed $(1 / 10.000 \mathrm{~g})$. Two procedures, named treatment 1 and treatment 2 were used with three repetitions each treatment. In the treatment 1 , the calcium determination was made according Pinheiro and Amato (1995), the shells were dissolved in $10 \mathrm{~mL}$ of chloridric acid $(\mathrm{HCl})$ concentrated $(12 \mathrm{M})$, and the solution obtained was a hundred times diluted in distilled water (1:100). From the diluted solution, were taken five aliquots of $25 \mathrm{~mL}$ each for calcium determination using ethylene diamino tetracetic acid dissodic (EDTA) according McCornick (1973). In the treatment 2, was tested an improvement of the technique described by Pinheiro and Amato (1995), to which the dried shells were transferred to a porcelain cubicle not porous, previously rinsed with nitric acid $\left(\mathrm{HNO}_{3}\right)$ concentrated. The shells were heated in a stove, at $450^{\circ} \mathrm{C}$ for 48 hours, to calcinate them. This occurred under temperatures above $250^{\circ} \mathrm{C}$ (Baccan et al., 2000) to eliminate the organic matter existing in the shell, remaining only the ashes containing the minerals. After that, the ashes were weighed and diluted in $50 \mathrm{~mL}$ of $\mathrm{HNO}_{3}$ and maintained in a digestor by six hours, adding $2 \mathrm{~mL}$ of hydrogen peroxide $\left(\mathrm{H}_{2} \mathrm{O}_{2}\right)$ to allow the clarification of the resulting solution. The sample were also diluted a hundred times and five aliquots of $25 \mathrm{~mL}$ each were taken for calcium determination using ethylenediamino tetracetic acid dissodic (EDTA) according McCornick (1973). The calcium carbonate mass was calculated using the volume of EDTA wasted in the titration process and expressed as $\mathrm{mg}$ of $\mathrm{CaCO}_{3} / \mathrm{g}$ of shell (treatment 1 ) or $\mathrm{mg}$ of $\mathrm{CaCO}_{3} / \mathrm{g}$ of ash (treatment 2).

\section{Statistical analysis}

The results obtained were expressed as mean \pm standard deviation and submitted to Student $\mathrm{T}$ test for mean comparison $(\alpha=5 \%)$ (InStat, GraphPad Prism, version 3.00 for Windows 95 and NT, Prism, Inc.).

\section{RESULTS}

The mass of the shells treated according the first procedure (treatment 1) was $1.5726 \mathrm{~g}$, wet weight (Table 1), and this value did not differ from that obtained to the wet weight of the shells submitted to treatment 2 .

The process of calcination of the shells, as described in the treatment 2 , resulted in a mean reduction of $34.02 \%$ in the mass of the samples of shells with a value equal to $1.5703 \mathrm{~g}$ (Table 2). 
Table 1 - Measurements made in the specimens of B. similaris that had their shell treated by $\mathrm{HCl}$.

\begin{tabular}{ccc}
\hline Number of Snails & Shell Weight $\mathbf{( g )}$ & $\begin{array}{c}\text { Calcium concentration } \\
\left(\mathbf{m g ~ o f ~} \mathbf{C a C O}_{\mathbf{3}} / \mathbf{g} \text { of shell) }\right.\end{array}$ \\
\hline 15 & 1.2187 & 590.8841 \\
15 & 1.0497 & 550.1006 \\
30 & 2.4494 & 682.3988 \\
Mean & 1.5726 & 607.7945 \\
\hline
\end{tabular}

Table 2 - Measurements made in B. similaris that had shells calcinated for 48 hours and digested for 6 hours.

\begin{tabular}{ccccc}
\hline $\begin{array}{c}\text { Number of } \\
\text { Snails }\end{array}$ & $\begin{array}{c}\text { Shell } \\
\text { Weight }(\mathbf{g})\end{array}$ & $\begin{array}{c}\text { Shell } \\
\text { Ashes }(\mathbf{g})\end{array}$ & $\begin{array}{c}\text { Mass } \\
\text { Reduction }(\boldsymbol{\%})\end{array}$ & $\begin{array}{c}\text { Calcium concentration } \\
\text { (mg of CaCO } \mathbf{3} \text { /g of ashes) }\end{array}$ \\
\hline 30 & 1.9007 & 1.7925 & 5.70 & 829.8419 \\
30 & 3.6282 & 1.9473 & 46.32 & 854.8698 \\
15 & 1.6110 & 0.9712 & 39.71 & 937.9942 \\
Mean & 2.3799 & 1.5703 & 34.02 & 874.2353 \\
\hline
\end{tabular}

The calcium content in the shell submitted to treatment 2 was, in average, $874.24 \pm 56.617 \mathrm{mg}$ of $\mathrm{CaCO}_{3} / \mathrm{g}$ of ash, being this value higher than that observed to the calcium content in the shells submitted to treatment 1 , where the mean value was $607.79 \pm 67.751 \mathrm{mg}$ of $\mathrm{CaCO}_{3} / \mathrm{g}$ of shell, wet weight (Fig. 1). When the data were submitted to $\mathrm{T}$ Student test by comparison of means $(\alpha=5 \%)$, the values obtained with the treatment 2 were significantly higher and different than those obtained with shells through the treatment 1 $(P<0.0005)$.

\section{DISCUSSION}

The treatment 1, presented a deficient result, because the use of $\mathrm{HCl}$ seemed not to destroy totally the organic matter of the shells, which was not completely oxidized. The organic matrix of the shells is constituted, mainly, by proteins and glicoconjugated, being secreted by the mantle cells into extraplial fluid, where it will be incorporated to the structure of the growing shell (Florkin and Scheer, 1972).

The shells of terrestrial snails may retain some organic acids found in the soil, as humic and fulvic acids. The humic acids are very strong complexing agents that compete with the EDTA by the calcium binding, altering the calcium determination in the shell by complexometric technique, if the shells present soil residues adhered to them.

The shells of terrestrial snails may retain some organic acids found in the soil, as humic and fulvic acids. The humic acids are very strong complexing agents that compete with the EDTA by the calcium binding, altering the calcium determination in the shell by complexometric technique, if the shells present soil residues adhered to them.

These acids are heterogeneous polymers and, according Haworth (1971), contain or quickly gave raise to a complex aromatic nucleus to which the polysaccharides, proteins, simple phenols and metals are attracted. The fulvic acids are humic substances less condensed and that exert an important role in the metals binding due to their great number of functional groups and occurred in a dissolved state (Shear and Watson, 1977).

The attractive strengths among the metallic ions and the soluble organic material colloidal or particulated in an environment may vary in a weak (physical adsorption) to strong range (chelating by organic matter) (Saxby, 1969). Thus, when $\mathrm{HCl}$ was used to aperture of the samples, a part of calcium ions $\left(\mathrm{Ca}^{++}\right)$is not determined by the complexometric method, once it may remains adsorbed to the organic matter of the shell and not reflecting the true value of the calcium concentration in the material (shell) analyzed, because these acids binding themselves strongly with calcium ion. 


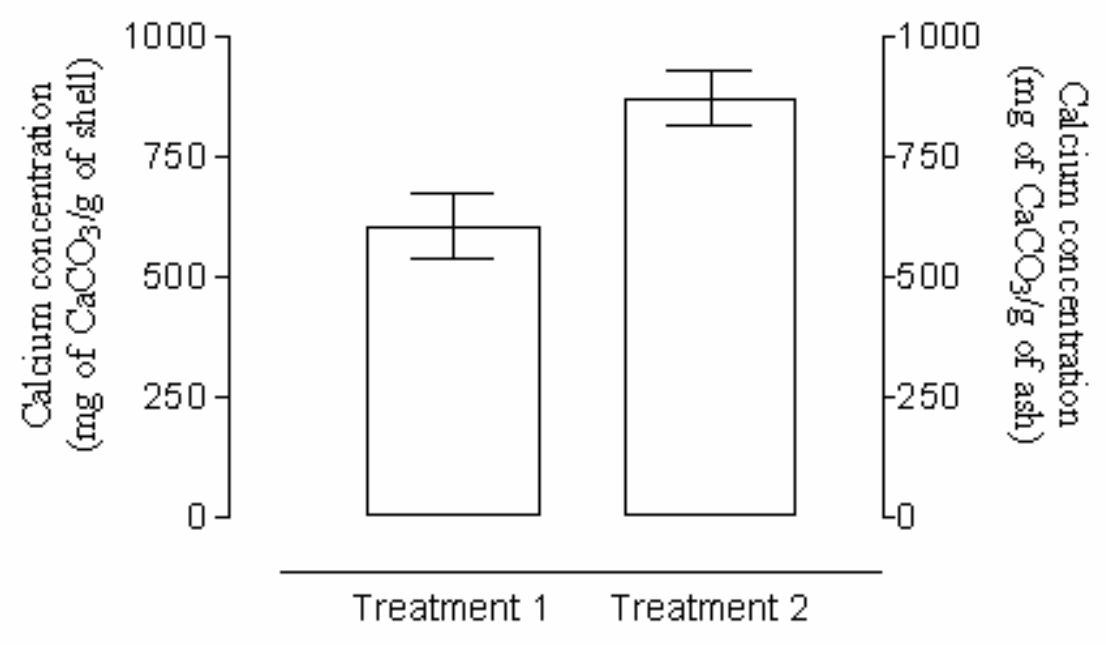

Figure 1 - Calcium content in shells of B. similaris expressed as $\mathrm{mg}$ of $\mathrm{CaCO}_{3} / \mathrm{g}$ of shell (treatment 1) and $\mathrm{mg}$ of $\mathrm{CaCO}_{3} / \mathrm{g}$ of ash (treatment 2) exposed to different treatments.

The samples opened in concentrated $\mathrm{HCl}$, room temperature, presented a high content of organic matter and a part of the calcium present in the shell remains bound in this organic medium. This organic matter may complexes to amino acids and other elements present in the medium, interfering to titration process (Shear and Watson, 1977).

When the results were expressed in ppm of $\mathrm{CaCO}_{3} / \mathrm{mg}$ of shell, wet weight, according Pinheiro and Amato (1995), the presence of organic matter may give us an erroneous interpretation because they not reflects directly the calcium alterations in the shell. Paschoal and Amato (1996) observed that in B. similaris infected with Eurytrema coelomaticum (Giard et Billet, 1892) the weight of the shell increases, but the calcium amount is reduced. So, Pinheiro and Amato (1995) technique must be masked and the results may not express the alterations in the calcium content in the shell, but they may be masked by the increase in the organic matter in the shell.

The opening of the shell in $\mathrm{HCl}$ resulted in a darkened medium and this may interfere with the identification of the changing of the color during the titration process used to determine the calcium content with the colored indicator murexide. Thus, the adding of $\mathrm{H}_{2} \mathrm{O}_{2}$, in treatment 2, makes the medium clearer avoiding possible errors in the titration process.

The treatment 2 presented advantages in relation to treatment 1 , because the calcinations procedure, at $450^{\circ} \mathrm{C}$ for 48 hours, caused a marked reduction in the mass of the shells (ashes), showing that the elimination of the organic matter occurred, completely, as well as the humic and fulvic acids. So, the interfering factors were excluded from the process.

The vestiges of organic matter that may remain in the medium after calcinations are eliminated by the use of the $\mathrm{HNO}_{3}$, a strong acid, which oxidizes this material, leaving the samples free of interferences. The shells treated according the second procedure showed higher content of calcium than the material treated according Pinheiro and Amato (1995) (treatment 1).

In spite of $\mathrm{HCl}$ be indicated by Baccan et al. (2000) as reagent to opening of samples of $\mathrm{CaCO}_{3}$, the $\mathrm{HNO}_{3}$ is used by some authors in digestion processes of samples to metals determination in snails shells (Carvalho et al., 2000), obtaining good results. Baccan et al. (2000), states that the opening in $\mathrm{HNO}_{3}$ is used to solubilization of some oxides and metals, while the $\mathrm{HCl}$ is used to solubilization of carbonated materials, and also, some oxides and metals. Although, the $\mathrm{HNO}_{3}$ has 
a higher oxidizing strength than $\mathrm{HCl}$, resulting an opening more efficient, also releasing the calcium bound to the organic matter.

According to results obtained, we may emphasize that the calcination of the shell before or its opening in acid medium is fundamental to the reduction of the organic matter that compose the shell. Beyond this, the use of $\mathrm{HNO}_{3}$, instead $\mathrm{HCl}$, resulted in a better opening of the shell, needing the addition of $\mathrm{H}_{2} \mathrm{O}_{2}$ during the digestion of the material for clearing of the solution avoiding interferences in the titration process. Thus, the treatment 2 showed to be efficient to calcium determination in snails shell.

\section{RESUMO}

O método complexométrico é geralmente utilizado para determinação quantitativa de cálcio em diferentes materiais; contudo a aplicação deste método à determinação de cálcio em conchas de moluscos infere significativas interferências aos resultados obtidos. O molusco Bradybaena similaris, um gastrópode terrestre, foi utilizado como modelo para aperfeiçoar este método. As conchas foram calcinadas e dissolvidas em ácido nítrico, o peróxido de hidrogênio também foi empregado para clarificar o meio após a adição do ácido. O processo de calcinação e o uso do ácido nítrico reduziram significativamente as interferências, permitindo um maior grau de destruição das substâncias orgânicas da concha. O aperfeiçoamento da técnica para determinação de cálcio empregado resultou em uma quantidade maior de cálcio igual a $874.24 \pm 56.617 \mathrm{mg}$ de $\mathrm{CaCO}_{3} / \mathrm{g}$ de cinzas em comparação com a técnica convencional que permitiu a determinação de $607.79 \pm 67.751 \mathrm{mg}$ de $\mathrm{CaCO}_{3} / \mathrm{g}$ de concha, peso fresco.

\section{ACKNOWLEDGEMENTS}

To Dr. Maria Aparecida A. Azeredo and Dr. Laerte da C. Azeredo, DEQUIM, UFRRJ, Brasil for the technical support to this study.

\section{REFERENCES}

Appleton, C. C. (1978), Review of literature on abiotic factors influencing the distribution and life cycles of bilharziasis intermediate host snails. Malacol. Rev., 11, 1-25.

Baccan, N., de Andrade, J.C., Godinho, O.E.S. and Barone, J.S. (2000), Química quantitativa elementar. $2^{a}$ edição. UNICAMP.

Brandolini, S. V. P. B. and Amato, S. B. 2001. Desenvolvimento de Eurytema coelomaticum (Giard et Billet) (Digenea, Dicrocoeliidae) em Bradybaena similaris (Férussac) (Gastropoda, Xanthonychidae).. Rev. Bras. Zool., 18, 499-510.

Carvalho, G. P. de, Cavalcante, P. R. S., Castro, A. C. L. de, and Rojas, M. O. A.I. (2000), Preliminary assessment of heavy metal levels in Mytella falcata (Bivalvia, Mytilidae) from Bancana river estuary, São Luís State. Rev. Bras. Biol., 60, 11-16.

Dawies, T. W. and Erasmus, D. A. (1984), An ultrastructural study of the effect of parasitism by larval Schistosoma mansoni on the calcium reserves of host, Biomphalaria glabata. Cell Tissue Res., 236, 643-649.

de With, N.D. and Sminia, T. (1980), The effects of the nutritional state and the external concentration of the ionic composition of the haemolypmh and on calcium cells in the pulmonate freshwater snail Lymnaea stagnalis. Proc. K. Ned. Akad. Wet., 83, 213-227.

Florkin, M. and Scheer, B.T. (1972), Chemical Zoology. Volume VII. P. Ed. Academic Press, New York.

Haworth, R. D. (1971), The chemical nature of humic acid. Soil Science, 111, 71-79

Lira, C. R. S. ; Pinheiro, J. ; Gomes, E. M. and Chagas, G. M. 2000. Influência do jejum severo sobre o conteúdo de proteínas totais e de amônio na hemolinfa de Bradybaena similaris (Gastropoda).. Rev. Bras. Zool., 17, 907-913.

McCornick, P. G. (1973), Tiration of calcium and magnesium in milk with EDTA. J. Chem. Ed., 50, 136.

Moreira, C. S. D. R., Gomes, E. M., Chagas, G. M. and Pinheiro, J. (2003), Calcium changes in Bradybaena similaris (Férussac, 1821) (Mollusca, Xanthonychidae) under starvation. Rev. Bras. Zooc., 5, 45-54.

Nduku, W. K. and Harrison, A. D. (1976), Calcium as a limiting factor in the biology of Biomphalaria pfeifferi (Krauss) (Gastropoda: Planorbidae). Hydrobiologia, 49, 143-170. 
Paschoal, S. V. and Amato, S. B. 1996. Eurytrema coelomaticum (Giard et Billet) (Digenea, Dicrocoeliidae) em Bradybaena similaris (Gastropoda, Xanthonychidae): alterações nos depósitos de cálcio e na funçào reprodutiva do primeiro hospedeiro intermediário. Rev. Bras. Zool., 13, 411-418.

Pinheiro, J. and Amato, S. B. (1995), Calcium determination in the Shell of Lymnaea columella (Mollusca, Gastropoda) infected with Fasciola hepatica (Platyhelminthes, Digenea). Braz. arch. biol. technol., 38, 761-767.

Pinheiro, J. 1996. Influence of starvation on the glycogen and galactogen contents in the snail Bradybaena similaris (Férussac, 1821) (Mollusca, Gastropoda). Braz. arch biol. technol.,39, 349-357.

Saxby, J. D. (1969), Metal-Organic Chemistry of The Geochemical Cycle. Rev. Pure Appl. Chem., 19, 131150.

Shear, H and Watson, A. E. P. (1977), The fluvial transport of sediment-Associated Nutrients and Contaminants. Ed. IJC/PLUARG.
Sminia, T., de With, N. D., Bos, J. L., van Nieuwmegen, M. E., Witter, M. P. and Wondergem, J. (1977), Structure and function of the calcium celss of freshwater pulmonate snail Lymnaea stagnalis. Neth. J. Zool., 27, 195-208.

Souza, R. M., Gomes, E. M., Chagas, G. M. and Pinheiro, J. 2000. The influence of starvation and eurytrema coelomaticum infection on the nitrogenous products of degradation in the hemolymph of Bradybaena similaris.. Braz. arch biol. technol., 43, 365-371.

Thomas, J. D., Benjamin, M., Lough, A. and Aram, R. H. (1974), The effects of calcium in the external environment on the growth and natality rates of Biomphalaria glabrata (Say). J. Anim. Ecol., 43, 839-860. 